\title{
VÁLLALATELMÉLETEK A CSOPORTTAGOK SZELEKCIÓS ELŐNYEINEK NÉZŐPONTJÁBÓL
}

A gazdasági evolúció folyamatában a szelekció elsősorban és döntően nem az egyének, hanem a csoportok szintjén zajlik. Korunkban, s kiváltképp a modern piacgazdaságokban a csoportszelekció alapegységei már jellemzően nem a családok, hanem a szervezetek, elsősorban a vállalatok. A vállalatok háromféle szelekciós előnyt tudnak elérni, s kínálni ezáltal a csoporttagok számára: 1) nagyobb egyéni teljesítmény, nagyobb egyénre „jutó" elérését, 2) nagyobb valószínűség és relatíve kisebb kockázatok, illetve mérsékeltebb bizonytalanság mellett, mindeközben 3) lehetővé téve az egyéni hozzáférést is a különböző anyagi és szellemi erőforrásokhoz, technológiákhoz. Többé-kevésbé a formális vállalatelméletekben is megjelennek mozaikszerűen ezek a dimenziók, azonban a legtöbbször nem kapnak kellő hangsúlyt. A csoporttagok nézőpontjából úgy tűnik, hogy van olyan vállalatelmélet, amely az evolúciós vállalatelmélethez képest is nagyobb szerepet szán a fenti három lehetséges szelekciós előny érvényesülésének.

Kulcsszavak: gazdasági evolúció, gazdasági szelekció, csoportszelekció, kockázat, vállalatelméletek

$\mathrm{A}$ gazdasági szereplők - a szervezetek és a természetes személyek - a mindennapi életben meg kívánják őrizni erősségeiket, esetleg növelni is szeretnék azokat. Másrészről nem kívánnák a gyengeségeiket szaporítani, lehetőség szerint csökkentenék is azokat. Mindezeket abból a célból, hogy a szelekció során relatíve kedvezőbb pozíciókat birtokolva egyfajta relatív szelekciós előnyre tehessenek szert. Az evolúcióban a mindenkori követelmények szerinti megmérettetés a szelekció által történik, így indokoltnak tünik az, hogy kiemelt figyelmet kapjon ez a terület. Ahogyan azt majd később látni fogjuk, lényeges kérdés, hogy a számunkra érdekes gazdasági szelekció elsősorban az egyénekre, vagy az egyének bizonyos csoportjaira irányul-e, s fejti ki hatását.

Nelson és Winter (1982) szerint a gazdasági evolúció alapmechanizmusa a biológiai evolúcióval egyező. Azaz, a populációban létező, mutációk, rekombinációk által létrejött variánsok, mutánsok közül az a típus növelheti részarányát, amelyik a külső és belső környezeti feltételeknek leginkább megfelel. Ugyanakkor jellemzően nem a szereplői reprodukció révén történik a sikeres minta térhódítása a gazdasági evolúcióban. Nelson és Winter (1982) álláspontja szerint a szelekciós kritériumok azok a követelmények, melyeknek való megfelelés szintje szerint határozódik meg a túlélés valószínüsége, illetve a túlélés állapoti jellemzői, azaz a túlélés kondíciói. A gazdasági szelekció során a variánsok a biológiaihoz képest lényegesen eltérően - döntően tudatos tevékenység révén - alakulnak ki, s a szelekciós kritériumok is jelentős mértékben az ember által, tudatosan határozódnak meg. Az „ember társas lény”, így a variánsok létrejötte, müködése, szelektálódása jellemzően nem egymástól elkülönült egyének szintjén valósul meg.

Csoport alatt az egymástól nem izolált egyének egy olyan érdekközösségét értjük, ahol a tagok között viszonylag rendszeresen történnek együttmüködő, reciprocitást feltételező interakciók, és ahol a tagok tevékenysége érdemi befolyást gyakorol egymás célmegvalósítási eredményességére (van den Bergh, \& Gowdy, 2008). A csoporttagok tehát függnek egymástól, bizonyos mértékű együttmüködésre, alkalmazkodás- ra, viszonosságra vannak ezáltal rászorítva. Különösen azért, mert ez a függés nem eseti, hanem a sorozatos interakciókból adódóan tartós jellegü. Ilyen módon csoportnak tekinthető az összes szervezet, s így a vállalatok is. De csoport lehet egy utca lakóközössége, egy család, vagy egy baráti kör is. A csoportok között lehet átfedés is, azaz egy személy több csoportnak is lehet egyidejüleg tagja. A tagsági viszony nem feltétlenül formális csatlakozás révén történik. Hasonlóan a szerződéskötéshez, itt is nagy szerepe lehet a ráutaló magatartásnak. Azaz, a más tagokkal való sorozatos interakciók realizálódása, s a többi csoporttagsági feltétel teljesülése esetén már egy csoporthoz való tartozásról beszélhetünk, anélkül, hogy formális csatlakozásra vagy felvételre sor került volna. Jelen tanulmányban a csoportok közül a vállalatokra fókuszálunk. A csoport fenti fogalmával összhangban, van den Bergh és Stagl (2003) szerint, a csoportszelekció során egy-egy közösség tagja elsősorban és döntően nem a többiektől elkülönülten, önállóan vesz részt a szelekcióban, hanem egy kisebb-nagyobb közösség, mint szelekciós egység részeként. Ilyen módon nem az egyes egyéni jellemzőknek önállóan, hanem a releváns csoportjellemzőknek kell megfelelniük a szelekciós követelményeknek. A csoport azért létezhet, mert a társakkal többé-kevésbé öszszehangolt tevékenységéből, „közelségéböl” az egyénnek valamilyen szelekciós elönye származik, származhat: növekszik a túlélési esélye, javulhatnak túlélési kondíciói. Ugyanakkor a csoport egésze is szelekciós előnyhöz juthat a relatíve nagyobb és sokszínübb populáció, illetve a szinergiák révén. A példaként közismert döntési helyzet, nevezetesen a „nagyobb torta kisebb, vagy a kisebb torta nagyobb hányada" itt is alkalmazható. A közös interakciók a csoporttagok részéről bizonyos mértékü összehangolódást, összecsiszolódást kívánnak meg, $\mathrm{s}$ ebben az esetben az alkalmazkodás a többi csoporttag számára biztosított egyfajta - több-kevesebb - „haszonbiztosítás” által térülhet meg. A csoport hosszabb távú müködése, fennmaradása abban is kifejeződik, hogy a csoporttagok között, illetve más csoportok felé rendre interakciók újabb és újabb sorozata zajlik le, azaz játékelméleti terminológiával élve, sokszorosan ismételt játékok valósulnak meg. 
Jelen tanulmány középpontjában a vállalatok állnak. Majd mindenki tagja valamilyen csoportnak: egy családnak, egy baráti közösségnek, egy lakóközösségnek. Ugyanakkor a modern piacgazdaságokban a nagy többség aktív korát vállalatoknál, vállalkozásoknál tölti el. A vállalattal összefüggésben csoporttagnak - a csoport korábbi meghatározásával összhangban - az alkalmazottakat, a menedzsment tagjait, illetve a tulajdonosokat tekinthetjük. Vagyis nem csak a vállalati szervezet tagjai csoporttagok. A munkaerö-piaci követelményeket - némi állami beleszólás mellett - a piac határozza meg, de végső soron a „frontvonalban” a vállalatok állnak. Ilyen módon a modern piacgazdaságok egyes csoporttípusai közül is jelentős, sőt meghatározó befolyással van a vállalati szektor - egyebek mellett - az egyének kompetenciáira is. Deming (2000) a csoport - a közgazdaságtan szempontjából elsősorban a vállalat, a szervezet -, mint támogató közeg fontosságát emelte ki. Az átlagos szervezetek némelyike alig tud többet nyújtani az egyénnek, de legtöbbjük jelentősen képes megemelni az egyénre jutó teljesítményt (1. ábra). A nem kis munka révén továbbfejlesztett szervezetek még inkább képesek támogató funkciójukat betölteni, illetve biztosítani az összehangoltságot, a tanulás folyamatos feltételeit.

\section{1. ábra Szervezetek többletteljesítményi potenciálja}

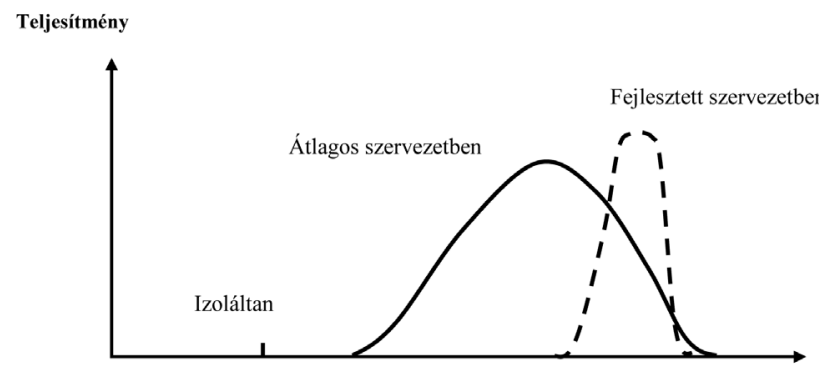

Szerveződés foka

Forrás: Deming (2000, p. 127) alapján saját szerkesztés

Tekintsünk tehát a vállalatokra e tanulmányban úgy, mint olyan csoportokra, melyek tagjaik számára potenciális szelekciós előnyöket kínálhatnak, jó esetben biztosíthatnak. A vállalatelméletek általános magyarázatot kívánnak nyújtani a vállalatok méretében megnyilvánuló életciklusra, miért jönnek, jöhetnek létre, miért növekednek, vagy miért tünnek el. A különböző vállalatelméletek leginkább egymástól eltérő növekedési-csökkenési mechanizmusokat nevesítenek, de számos esetben hasonló okokat is megjelölnek a vállalati lét tekintetében. Ebben a már-már zavarba ejtő sokszínűségben segíthet tájékozódni a csoporttagok szelekciós előnyeinek általánosan, minden vállalatelmélet esetében alkalmazható nézőpontja.

\section{A vállalati lét lehetséges szelekciós előnyei}

Mielőtt a későbbiekben a formális vállalatelméleteket áttekintenénk, célszerü meghatározni, hogy a csoporttagok milyen típusú szelekciós előnyeit szem előtt tartva történhet meg majd ez az áttekintés. Így ebben a fejezetben arra a kérdésre keressük a választ, hogy miben, milyen módon lehet általában egy vállalatnak szelekciós előnye az önálló szereplővel szemben. Ez azért fontos, mert a vállalat ebből az előnyéből tud majd a csoporttagok számára valamilyen módon és formában juttatni.
Holmström és Tirole (1989, p. 65) négy alapvetö kérdés tisztázását tartja fontosnak, hogy egy vállalat létrejöttét, müködését, fejlődését, fennmaradását megfelelő szakszerűséggel magyarázni lehessen:

1. Milyen módon határozódnak meg a vállalat határai, és mi magyarázza ezek megszilárdulását?

2. Milyen módon határozódik meg a vállalat tőkeszerkezete?

3. Milyen mértékben és módon szeparálódnak el a tulajdonosok, és milyen módon tudják ellenőrzésük alatt tartani a vállalatot?

4. Milyen a vállalat belső hierarchiája, hogyan illeszkednek ebbe a döntéshozatali és ösztönzési struktúrák?

Chikán (2014) fontosnak tartja, hogy a közgazdaságtani elméletek, illetve az üzleti szférát elemző gazdálkodástan között egyfajta híd jöjjön létre. Hét vállalatelméletet elemző munkájában módszertani kiindulásképpen azt javasolja, hogy az egyes vállalatelméletek tanulmányozását megelözöen érdemes azok általános fogalmi hátterét tisztázni. Ehhez Douma és Schreuder (1991) fogalmi kereteit használja, amely a következö tényezöket foglalja magában:

1. társadalmiszükséglet-kielégítés szükös erőforrások mellett,

2. hatékonyság,

3. munkamegosztás, specializáció,

4. tevékenységcsere,

5. koordináció szükségessége,

6. információ.

Ebből kiindulva, a csoportszelekcióval összefüggésben, tehát tekintsük át azt, hogy az - akár izoláltan, akár versenyközegben való - egyéni tevékenységhez képest milyen előnyt jelenthet egy vállalat keretei között megvalósuló tevékenység. Azaz, hogyan, és legfőképpen miért füződnek le egyéni szereplök az alapsokaságukból, s alkotnak valamilyen szelekciós előny megszerzése céljából valamilyen közösséget, szervezetet, kiváltképp vállalatot. Kapás (1999a, p. 36) ezen, több nézöpontból is vizsgálható problémát találóan úgy fogalmazta meg, hogy „mi a vállalat létének az oka?” Az alábbiakban (1. táblázat) tíz olyan alapvető okot tekintünk át, amelyek korszaktól, gazdasági rendszertől függetlenül közös munkára sarkalták az egyéneket, tekintettel az anyagi forrásokat, eszközöket biztosító - és a munkavégzésben közvetlenül nem közremüködő - személyekre is.

1. táblázat A vállalatok mint a csoportszelekció sajátos esetei által a csoporttagok részére biztosított lehetséges szelekciós előnyök típusai

\begin{tabular}{|l|l|}
\hline \multicolumn{2}{|c|}{ Előnybiztositódás lehetséges típusai } \\
\hline 1/ Csoportmunka & 6/ Termékdiverzifikáció \\
\hline 2/ Munkamegosztás & 7/ Szinergia elérése \\
\hline 3/ Méretgazdaságosság & 8/ Egyéni fejlődés összecsiszolódás révén \\
\hline $\begin{array}{l}\text { 4/ Kockázatok csökkentése, } \\
\text { kezelése }\end{array}$ & 9/ Egyéni fejlödés kommunikáció révén \\
\hline 5/ Bizonytalanság csökkentése & 10/ Egyéni fejlődés tudásbank révén \\
\hline
\end{tabular}

Forrás: saját szerkesztés

Egyes tevékenységek csak jól szervezett csoportmunka révén végezhetők el, ilyen például a hajóépítés és hajózás. Amennyiben e tevékenységek összességében és egyénekre 
lebontva is megfelelően magasabb hozamokat eredményeznek, úgy a többiekkel szemben elönybe kerülhetnek saját céljaik eredményesebb elérése érdekében (Progoulaki \& Theotokas, 2010). A csoportmunkának, vagy csoportos termelésnek nincs érdemi alternatívája, mert külön-külön egyik részt vevő, vagy a részt vevők kisebb csoportja sem birtokol annyi releváns inputtényezőt - alapvetően munkaerőről van szó amelyek révén az adott output előállítódhat. A gond ott kezdődik, hogy adott - valamennyire heterogén - közösségből, mint merítési bázisból meghatározásra kerüljön a minimális csoportlétszám, amely mellett az adott output már - megfelelő minőségben - előállítható. Ez lenne a vállalat induló optimális mérete. Ennek pontos nagysága azonban ritkán állapítható meg, így egyes tagok potyautas tevékenysége rontja a hatékonyságot (Demsetz, 1997), miközben az új munkavállalók megfelelő szervezeti szintű integrációjával jelentős javulás is elérhető (Kozák, 2015).

Amennyiben egy jószág előállításának teljes folyamata szakaszokra bontható, továbbá az egyes szakaszokra való specializálódás - vagyis a munkamegosztás - növeli a jószág-előállítás hatékonyságát (Smith, 1776), úgy megfelelő keresleti viszonyok esetén előnyös lehet vállalat keretein belüli releváns tevékenység. Elvileg minél nagyobb volumenben termelő vállalat, annál inkább van valós lehetősége a még nagyobb mértékü munkamegosztásra. Nyilvánvaló, hogy ezáltal nem feltétlenül kevesebb az abszolút inputfelhasználás, de tipikusan nagyobb a termelékenység s a hozamok (Basu, Pascali, Schiantarelli \& Servén, 2009).

A méretgazdaságosság is meghatározó szempont lehet. A vállalaton belüli munkamegosztás ebben az esetben is eredményez a nagyobbaknál hatékonyságnövekedést, ugyanakkor bizonyos termelési nagyság alatt egyszerüen nem képződhet megfelelő nyereség - tekintettel az aktuálisan elérhető input és output piaci árakra. Tehát amennyiben a szereplőnek mindenképpen az adott iparágon belül szükséges valamilyen feltételek miatt maradnia, úgy az csak a kritikus üzemi méretet elérő vállalati léten, s jellemzően - egy bizonyos szintig - minél nagyobb vállalatként hozhat számára megfelelő eredményességet (Baumers et al., 2016). A profit szerint értelmezett méretgazdaságosság két pilléren nyugszik. A beszerzéseknél, az alapanyagoknál, a technológiáknál is szükséges elérni egy bizonyos üzemméretet, hogy egyáltalán hozzáférhetővé váljanak a termelő számára ezek az inputok. Másrészt a kibocsátásban is sok esetben meg kell haladni egy bizonyos korlátot annak érdekében, hogy bizonyos piacokhoz legyen képes hozzáférni a termelö.

A kockázat csökkentése és kezelése a fennmaradás és fejlődés egyik központi kategóriája. A kockázat kedvezőbb állapoti jellemzőkkel csökkenthető, hiszen megnő az esélye annak, hogy az adott tevékenységet képes uralni a szereplő, ezáltal képes elkerülni a számára kedvezőtlen kimenetek megvalósulását. Nagyobb tudással, erőforrások nagyobb mennyiségével, érdemi döntési alternatívák bővülésével jellemzően kisebb kockázattal kell a szereplönek szembesülnie. A portfólió-elmélet (Markowitz, 1952) alkalmazásának széles körü elterjedésével mára már általánosan elfogadottnak tekinthető, hogy a kockázat mértékét jelentősen csökkentheti a diverzifikáció. Nash és Mccloskey (1984) matematikai modellel is igazolták Mccloskey korábbi (1976) hipotézisét, amely szerint a középkori Angliában elsődlegesen azért hoztak létre a földmüvesek termelöi közösségeket, hogy az esetleges egyéni veszteségeket a közösség tagjai között szétterítve képesek legyenek stabilizálni a tagok gazdálkodását, minimalizálni az esetleges egyéni veszteséget, ugyanakkor az egyéni tartalékolási szükségleteket is.

Simon (1947) a szervezet létét részben döntéselméleti alapokra helyezte. A gazdasági szereplök általában, de különösen az egyediek korlátozott racionalitással jellemezhetőek. A szervezetbe kerülve az egyén jelentős mértékben mentesülhet attól a bizonytalanságtól, melyet a többi szereplő szimultán, $\mathrm{s}$ jelentős módon nem elöre jelezhető tevékenysége okoz. A többi releváns környezeti tényező esetében a csoport rendelkezésére álló, feltételezhetően nagyobb tudás révén is csökkenhet a bizonytalanság. Harmadrészt, - jó esetben - az egyének szubjektív döntéshozatalából adódó nagyobb alternatív költséget csökkentheti a testületi döntéshozás. Mindehhez jó alapot kínál az, hogy a csoporton belül a tagok tevékenysége relatíve jobban össze van hangolva, ráadásul stabilabb keretek között. A kiszámíthatóbb viszonyok miatt mód nyílik a szereplő számára racionálisabb, eredményesebb célmegvalósítást lehetővé tevő döntések meghozatalára.

A termékdiverzifikáció révén a vállalat bővíti termékpalettáját, méghozzá úgy, hogy eközben fenntartja, sőt növeli is hatékonyságát bizonyos területeken. Penrose (2009) rámutat, hogy minél kisebb egy vállalat, jellemzően annál kevesebb féle jószágot állít elő. Egy kisvállalat, - kiváltképp egy egyéni szereplő - nem képes több fajta jószág esetén sem olyan mennyiség előállítására, amely a munkafolyamatok vonatkozásában kellő hatékonyságot biztosító munkamegosztást tenne lehetővé. Ugyanakkor a kisebbeknél gyakran, szük keresztmetszetként a termelési volument meghatározó képességek - például tudás, finanszírozás - sem állnak elégséges mértékben rendelkezésre több jószág piaci igényeknek megfelelő előállításához. Penrose (2009) szerint az innovációk terén is megnyilvánul a nagyobb vállalatok egyfajta szelekciós előnye a kisebbekkel szemben, hiszen ők gazdasági erejüknél fogva képesek „,öbb vasat is egyszerre a tüzben tartani”, ami jelentösen csökkenti a vállalkozás innovációs kockázatát. Ugyanakkor mivel náluk nagyobb az esélye a sikeres innovációnak, a tartós fennmaradás valószínüsége is kedvezőbb lehet e szempontból számukra a jelenlegi gyorsan változó világban.

A csoportban tagként lehetőség nyílik arra, hogy egyes olyan fontos, de kedvezőtlen egyéni tulajdonságok, hiányosságok - melyeket a szelekció megtorolna, amennyiben a szereplő egyedül méretné meg magát - megkerülhetővé váljanak (Lewis, 2004). Így a csoportok megteremtik a lehetőséget a tagok eltérö adottságainak szinergiájára - a gyengeségek tényleges felszámolása nélkül. Ennek révén a csoport sokkal hatékonyabb lehet akár a felhasznált erőforrások mennyisége, akár az idő tekintetében. Ebben az esetben tehát nem előnyös tulajdonságok hiányának kiküszöbölődéséről, hanem kifejezetten hátrányos egyéni tulajdonságok mellőzhetőségéről van szó. Az egyéni szelekció ilyen módon torzulást szenved, ami ugyanakkor nem egyértelmüen hátrányos a populációra nézve. Az egyedileg nem élenjáró - következésképpen olcsó - játékosok megfelelö összeválogatásával, hozzájuk illő stratégiával, taktikával akár bajnokcsapat is létrejöhet, ahogy azt a Moneyball címü bestseller is bemutatta (Lewis, 2004). A közgazdász szakma is felfigyelt erre a példára, további elemzéseket szolgáltatva (Surendra \& Denton, 2009). 
March és Simon (1958), később Cyert és March (1963) a vállalatok keletkezése kapcsán egyik meghatározó lehetőségnek az érintett szereplők magatartásának, tevékenykedésének összehangolódását tartotta. E magatartási koncepció szerint egyes szereplök felismerik azt, hogy céljaik, vagy céljaik egy része, illetve azok megvalósítási tevékenysége közös, azaz egymással összeegyeztethető, sőt az összehangolás révén az egyéni kedvező tulajdonságok terén még fejlődés is várható. Így ők egyfajta sajátos szövetségre lépnek egymással, hogy közösen munkálkodjanak céljaik elérése érdekében. Cyert és March (1963) hangsúlyozza, hogy nem feltétlenül azonos cél érdekében kell valamennyi tagnak összefognia, de ezek a célok, az ezekhez vezető lehetséges utak ne zárják ki eleve egymást, legyen közös metszete az egyéni célok megvalósítási tevékenységeinek, s ez a közös metszet a vállalati, szervezeti célokban öltsön testet, fejeződjön ki. A közös érdeknek tehát ebben az esetben minimálisan a közösen végezni kívánt tevékenységeknek, azok sikerességének kell lennie.

A szervezet stabilabb és több szempontból is hatékonyabb kereteket ad a szereplők közötti kommunikációhoz. A nem izolált szereplők között ugyanis szükségképpen kialakul valamilyen kommunikáció. Természetesen ez folyhat a piaci szereplők között is, formális, illetve informális módon. Korlátozódhat csak az árakra, de még inkább kiegészülhet más információk továbbításával, feldolgozásával. A kommunikáció központi szerepet tölt be a szereplők együttmüködése, de bármilyen más kapcsolatrendszere vonatkozásában is (Simon, 1947). A hatékony kommunikáció részben a kisebb költségekben nyilvánul meg, részben a szervezeti kultúra adta közös nyelvben és értékrendben, melyek révén az üzenetek kisebb torzítással érhetnek célba. Bolton és Dewatripont (1994) hangsúlyozzák, hogy a vállalatot egy kommunikációs hálózatként kell felfognunk, $\mathrm{s}$ a szervezeten belüli kommunikáció feltételeinek további javítása - például költségeinek, időigényének csökkentése - révén a szervezet müködése még eredményesebbé válik. Az eredményesség növelésének ez egy lényegi módja, pontosan abból adódóan, hogy a szervezet jelentős részben pont a hatékonyabb kommunikáció igénye miatt jött létre.

Simon (1947), később Nelson és Winter (1982) is hangsúlyozta a szervezet azon szerepét, hogy mesterséges memóriaként képes a tudás megőrzésére. Az egyén ilyen jellegü kapacitása korlátozottabb, ráadásul a tudás egy szereplő általi megörzése kockázatosabb is. Ez nagyon sérülékennyé tenné az olyan fejlődési pályákat, ahol a tudásnak, a tudatosságnak lényegi szerepe van. Kapás (1999a, p. 827) a vállalat gazdasági „génje” alatt egy olyan egységet ért, amely képes az információátörökítő mechanizmusban részt venni, s általa a vállalat bizonyos jellemzői a következő időszakra átvivődnek, megőrződnek. Egy szervezetben nagyobb az esély a tudás fennmaradására, minél nagyobb a szervezet, jellemzően annál inkább. A külső tudás átvételének szervezeti korlátai vannak. Ezek meghatározzák a szervezet abszorpciós kapacitását, amely a változó körülményeknek való minél nagyobb mértékü megfelelése kapcsán fontos tényezője a túlélésnek (Zerwas, 2014).

Amennyiben az egyéni önálló munkavégzésben reaktív szelekciós hátrány áll fenn, a fenti tíz alternatíva bármelyike külön-külön is alkalmas arra, hogy az egyént egy vállalatbeli együttmüködés, azaz a szelekciós előny megszerzése irányába terelje. Az igencsak sokszínű vállalatelméletek fenti tíz, relatív szelekciós hátrányt kiküszöbölő alternatíva szerinti áttekintése azonban nem igazán tudna egy megfelelően világos képet rajzolni elénk. Célszerű tehát a tíz tárgyalt szelekciós előnyszerzési mód megfelelő strukturálása. Egyrészről 1) az egyén a vállalat révén képes hozzáférni bizonyos többlet erőforrásokhoz, technológiákhoz, illetve más személyek tudásához, tapasztalataihoz. Ebbe a csoportba sorolhatjuk a méretgazdaságosság, a kommunikáció, illetve a tudástár alternatívákat. Megjegyzendő, hogy sok tevékenységi kockázat, illetve ahhoz kapcsolódó bizonytalanság a nagyobb releváns tudás révén érdemben csökkenthető. Másrészről 2) az egyéni szereplő szervezeti megoldások révén is szeretné csökkenteni az általa mások szimultán tevékenysége miatt vállalni kényszerült kockázatot, illetve bizonytalanságot. Ebbe a csoportba sorolhatjuk az ilyen jellegü kockázat- és bizonytalanságcsökkentés, a termékdifferenciálás és az öszszehangolás iránti igényeket. Végül, 3) az egyén nem öncélúan kíván hozzáférni anyagi, szellemi erőforrásokhoz, technológiákhoz, nem önmagában a tevékenységi kockázatait és bizonytalanságát kívánja csökkenteni, hanem már relatíve rövid távon is eredményesen szeretné céljait megvalósítani. Ide tartozhat a csapatmunka, a munkamegosztás és a szinergia által eredményezett hatékonyságjavulás.

A csoportszelekcióban tehát azok a csoportok képesek megfelelően erős vonzerőt gyakorolni a tényleges és a lehetséges csoporttagjaikra, amelyek:

1) hozzáférnek a megfelelő anyagi és szellemi erőforrásokhoz, technológiákhoz,

2) szervezeti megoldásokkal jelentősen képesek a kockázatot és a bizonytalanságot csökkenteni,

3) mindeközben képesek a csoporttagok (rövid távú) célmegvalósítási eredményességét is kellőképpen támogatni.

A továbbiakban a formális vállalatelméleteket úgy tekintjük át, hogy e három kategóriát tartjuk szem előtt, értékelve, hogy az adott elmélet mekkora súlyt helyez a csoporttagok szelekciós előnyeire.

\section{Formális vállalatelméletek}

Kétségtelen tény, hogy a vállalatok általános, nem jogi értelemben vett alapítása, egy tudatos próbálkozása a benne résztvevőknek - akik nem feltétlenül csak a tulajdonosok -, hogy valamilyen szelekciós előnyhöz jussanak. A vállalat mint csoport egy tudatos és mesterséges képződmény, ahol csak célzatosan, tudatosan lehet csoporttaggá válni.

A neoklasszikus vállalatelmélet a vállalat mint rendszer létét, müködését elsődlegesen a környezetével folytatott „anyagcseréje” révén határozza meg. Azaz a vállalat egyediségét úgy kívánják megragadni, hogy a felhasznált inputokat, illetve ezek átkonvertálása révén keletkezett outputokat helyezik egymás mellé (Hicks, 1946). Az így létrejövő input-output kombináció egy sajátosan egyedi mintázatot ad, egy ,ujjlenyomatot”, mely csak az adott vállalat sajátja. Hicks (1946) a Schumpeter-féle vállalkozót, a maga kreativitásával, ambícióival is az inputok közé sorolja. Azt, hogy ténylegesen milyen módon történik az inputok outputtá való átkonvertálása, az bizonyos mértékig rejtve marad az úgynevezett fekete dobozban. Kornai - akit Bockman (2011) már egyenesen 
neoklasszikus közgazdásznak minősít - Anti-equilibrium (1971) című munkájában egységnek a gazdasági rendszer azon alkotóelemeit tartja, amelyek további életképes elemekre már nem bonthatók, és az őket érő hatásokra szabályszerüen válaszolnak. Kornai (1971, p. 67) ugyanitt bevezeti a válaszfüggvény fogalmát is, mint ,az egységbe bemenő input és az egység indulóállapota, valamint az egységből kimenő output és az egység állapotváltozása közötti összefüggést”. Kornai (1971) ezzel túllép a termelési függvény elméletén, hiszen a válaszfüggvényben közvetlenül megjelennek a szereplö állapoti jellemzői is, melyek a termelés, illetve tevékenysége folytatása révén folyamatosan változnak. A neoklasszikus vállalatelméletben a vállalatok léte adottság. Méretük a technológiai, a pénzügyi, illetve a kereslet-kínálat viszonyaihoz - mind az input, mind az output oldalon - való alkalmazkodásukhoz szükséges idő függvénye. A kockázatok és a bizonytalanság figyelembevételével a vállalatok nem standardizálható válaszokat adnak. Ezek - különösen az erre adandó szervezeti válaszok - legfeljebb Kornai (1971) modelljébe építhetők bele. A csoporttagok összetételének, egyéni ,,jutóinak" nincs, és nem is lehet ebben az elméletben jelentősége, hiszen minden csoporttag azonos tudással, preferenciákkal, és egyéb jellemzőkkel bír, döntéseiket matematikai alapon hozzák. A csoporttagok közül a tulajdonosok érdeke - mögöttesen - megjelenik az elméletben, esetükben a matematikai alapon hozott döntésekre vonatkozó feltételezések nem is tekinthetők annyira eltúlzottnak.

Penrose (2009) az erőforrás vállalatelmélet ,nagyasszonya" a vállalat létrejöttét nem egyfajta költségmegtakarításként értelmezte, mint a későbbiekben tárgyalt tranzakciós költség elmélete. A vállalat szerinte annak köszönheti létét, hogy olyan egyedi eröforrás kollekciót tudhat magáénak, mely lehetővé teszi, hogy a piaci, iparági versenyben előnyt szerezzen, élvezzen, járadékhoz jusson. Ameddig erőforrásai révén versenyelönye létezik, addig a vállalat fennmarad, rendszerként részben elkülönül környezetétől, de azzal folyamatos kapcsolatban is áll. Közvetve a piac szab határokat a vállalat méretének, hiszen a versenyben sikeres vállalat további eröforrásokra tesz szert, a vezetés és a tulajdonosok mérlegelik, érdemes-e folytatni az erőforrásgyüjtést és -fejlesztést, vagy a vállalat elérte az adott piac szerinti leghatékonyabb állapotát, esetleg az erőforrások át is csoportosíthatók tőle. A költségek természetesen ebben az elméletben is fontosak, hiszen az erőforrások létrehozása, gyüjtése, fejlesztése, maga a termelés ráfordításokat igényel, amit kedvező erőforrás-kollekció birtoklása, müködtetése esetén megfelelő árbevétel ellensúlyoz, megfelelő profit létrejötte mellett. Penrose (2009, p. 11) hangsúlyozza, hogy a bizonytalanság és a kockázat mértéke ugyancsak behatárolja a vállalati méretet, hiszen a költségek és a bevételek tervezhetősége és realizálódása különböző vállalatméretek esetén különböző lehet. Penrose (2009) egyáltalán nem szűkítette le az erőforrás-kollekcióját anyagi jellegü javakra, külön fejezetet is szentelt az emberi erőforrásoknak, illetve azok anyagi erőforrásokra gyakorolt hatásának. Nagyobb tudás - álláspontja szerint - nagyobb termelékenységet, hatékonyságot eredményez, következésképpen közvetlenül vagy közvetetten, de kedvezően hat más erőforrások mennyiségre és összetételére. Az erőforrás-alapú vállalatelmélet matematikailag kevésbé modellezhető, amelynek oka, hogy már figyelembe veszi a vállalatok sokszínüségét, benne az észlelt, illetve vállalni kényszerült kockázatokat és bizonytalanságot, vagy a rendelkezésre álló tudást is. A vállalatok egyedi azonosítására alkalmas erőforrás-összetételi kombináció nemcsak a sokféle fajtájú és minőségű anyagi erőforrástól válik specifikussá, hanem az eltérö tudással, tapasztalatokkal rendelkező humán eröforrás miatt is. A csoporttagok ,jutóra” vonatkozó eltérő elvárásait már figyelembe veszi ez a vállalatelmélet, de érdemi fontosságot nem tulajdonít neki a csoport létrejötte és müködése tekintetében.

A tulajdonosi jogok elmélete (Hart \& Moore, 1990) abból indul ki, hogy a mindennapi életben nagyon ritka az ún. tökéletes szerződés. A tökéletes szerződésben minden lehetséges jövőbeni kimenethez olyan következmény van rendelve, amely minden szerződő felet kielégít mind a szerződés megkötésekor, mind annak érvényesítése során. A nem tökéletes szerződések vagy nem képesek lefedni az összes kimenetet, vagy az azokhoz rendelt következmények kölcsönös elfogadásával, elfogadhatóságával vannak problémák. Ez a vállalatelmélet tehát a tulajdonosi jogok érvényesítésére fókuszál. Megkülönböztethetünk anyagi vagy szellemi jellegü tulajdont. Az üzleti életben a fö kérdés a tulajdonokkal kapcsolatban Hart és Moore (1990) szerint az, hogy a tulajdonosi jogokat milyen mértékben lehet érvényesíteni, hiszen az érvényesítés hatékonysága meghatározó a tulajdonból származó lehetséges hasznok realizálásakor. Ugyanakkor a tulajdonosok tulajdonosi jogaikkal élve befolyásolni tudják más érintettek tevékenységét, amikor tulajdonukat, annak hozamát, hozadékát felhasználják. E két motívum határozza meg Hart és Moore (1990) szerint, hogy megalakul-e a vállalat, vagy miként alakul a vállalat mérete, milyen tulajdont, milyen módon integrál magába. Mint hiányos szerződésekkel foglalkozó elmélet, ez is nagy hangsúlyt helyez a kockázatok és a bizonytalanság kezelésére. Miután azonban ez alapvetően nem jogi, hanem közgazdasági elmélet, így meghatározó e problémák szervezeti megoldásokkal való feloldásának törekvése. Bár az erőforrások közül elsősorban az anyagi, illetve az önállóan is piacképes szellemi tulajdonra fókuszál, összességében mindezek fontosságának megítélésekor sok rokon vonást mutat az erőforrás-alapú elmélettel. Az erőforrások, technológiák felhasználása, kombinációik létrehozása azonban itt elsősorban az alapján dől el, hogy a tulajdonosi jogokkal milyen mértékben élnek, nem a „mérnöki”, de nem is tisztán a profitmaximalizálás szempontjai a meghatározóak. A csoporttagok részére is inkább kiszámítható, ellenőrzés alatt tartható, tervezhető, illetve stabil tulajdonviszonyokon alapuló rendszert ígér, miközben a tevékenységi kockázatok elmélet általi mellőzése miatt az anyagi előnyök és hozamok továbbra is nagymértékben bizonytalanok maradhatnak.

Cyert és March (1963) magatartási elméletnek nevezte azt a vállalatelméletet, ahol a kulcselem az érintettek összefogása, összehangolódása, de nem elsődlegesen egy vállalati cél, hanem saját egyéni boldogulásuk érdekében. Cyert és March (1963) a résztvevők vállalatban történő „összefogását” egyértelmüen a hatékonyabb egyéni szükségletkielégítés iránti vággyal indokolják. A vállalat alapításában és müködésében érdekeltek mindegyike a saját érdekei és mércéje szerint kívánja a vállalat segítségével meghaladni az egyéni tevékenykedésük adta lehetőségeket, elérni egy számukra egyedileg 
kívánatos aspirációs - „megfelelőségi” - szintet. A szelekciós elöny megszerzése, annak igénye itt bizonyos értelemben az egyénnek önmagával szemben is fennáll, de természetesen ugyanúgy a többi egyéni és szervezeti szereplővel szemben is. Minden résztvevő saját egyéni célokkal, aspirációs szintekkel, illetve erőforrásokkal - közöttük a tudásával - vesz részt a vállalat mint érdekközösség alapításában, müködtetésében. A vállalati ,gazdasági génállomány” ebben az esetben, mint az érintettek fenti jellemzőinek sajátos eredőjeként jelenik meg, kap és hordoz egyedi mintázatot. A vállalat addig marad fenn, amíg az érdekeltek meghatározó hányada eléri egyéni aspirációs szintjét, majd bővül, ha képes új résztvevőket kölcsönösen előnyös ajánlatokkal megnyerni. A bővülés ellen hathatnak az információszerzés, az összehangolás és a döntéshozatal megnövekedett költségei. Chikán (2005, p. 66) kiemeli, hogy a magatartási elmélet „,a vállalatot nem cselekvő egészként, hanem az érintettek koalíciójaként fogja fel”. Ez a vállalatelmélet már kiemelten kezeli a csoporttagok eltérő sajátosságait mind a tudás, mind az érdekek, illetve a célok - kiváltképp a ,jutók” - tekintetében. Úgy tünik azonban, hogy így egyfajta átváltás érvényesült, méghozzá elsősorban az anyagi erőforrásokhoz való hozzáférésben. Az anyagi erőforrások az őket tulajdonlók vállalati koalícióba való beemelésétől függően válhatnak a vállalat számára hozzáférhetővé, ám ez nem a koalícióalakítás meghatározó szempontja. Ettől függetlenül, egy megfelelő összetételü csoport létrehozásával jó esetben hozzáférhetővé válnak mindazok az erőforrások - beleértve a tudásjellegüeket is -, amelyek a vállalat aktuális operatív és stratégiai céljainak megvalósításához szükségesek lehetnek. A kockázatoknál és a bizonytalanságnál a szervezeti válasz csak a koalíció megfelelö összetételének biztosítására szorítkozik.

A magatartási vállalatelmélet nagyon közel helyezkedik el Alchian és Demsetz (1972) csoportos termelésröl vallott nézetrendszeréhez. Azonban míg a magatartási elméletnél a kiindulópont az egyének sajátosságaiból fakadó koalícióépítési hajlandóság, a csoportos termelés esetében a termelés technológiai szükségszerüségeiből fakadó a meghatározott humánerőforrás iránti igény. A termelés szükségszerüségei alatt nem kizárólag a technológia igényei értendőek, mint például a vitorlás hajó gyártása vagy müködtetése esetén, amikor egy minimális, meghatározott tulajdonságokkal bíró csoport megléte nélkül a tevékenység érdemben el sem kezdhető. A termelés részéről szükségszerüség lehet az a kényszer, hogy meghatározott idő alatt meghatározott mennyiségű outputot kell előállítani. A csoportos tevékenység sok szempontból hatékonyabb az egyéni tevékenységhez képest, a potyautas jelenség feltünése viszont e hatékonyságon rést üthet. E rés csökkenthető a csoportos tevékenység létszámának csökkentése, vagy a szervezet másféle müködtetése, illetve tagcsere révén. Ez a vállalatelmélet kiemelt figyelmet fordít a csoporttagok ,jutójára”, amely az ellenértéke annak, amivel képesek és hajlandók hozzájárulni a közös munka létrejöttéhez. A csoport szerveződési elve erőforrás-központú, hiszen az egymáshoz illeszkedő, egymást igénylő erőforrásokkal rendelkezők be- és összeszervezése révén alakulhat meg és müködhet a csoport. Az erőforrások közül kitüntetett figyelmet élveznek a humán erőforrások, illetve az általuk megszerzett tudás. A kockázatok és a bizonytalanság szerepe lényegében arra korlátozódik ebben az elméletben, hogy a csoport megalakulása révén az egyéni releváns szintek drasztikusan csökkenhetnek. Főként emiatt lehet a csoportos tevékenység által eredményezett közös torta egyéni ,jutója” sokkal ígéretesebb, mint egy önállóan létrehozott torta.

Chandler (1990) a humán erőforrás vonatkozásában a menedzsment szerepét tartotta kulcsfontosságúnak. Mégpedig azért, mert ők döntenek a vállalat beruházáspolitikájáról, s ezáltal irányt szabnak a fejlődésnek. A beruházások révén újulnak meg és bővülnek a vállalat erőforrásai, tehet szert előnyre versenytársaihoz képest. A menedzsment gyakran elkülönül a tulajdonosoktól, már csak a vállalatok mérete kapcsán is. Ugyanakkor vállalatelméletként a megbízó-ügynök elmélet$n e k$ is elsődlegesen arra kell választ adnia, hogy mi a vállalat létezésének oka. Az, hogy a megbízó-ügynök viszonyrendszer ettől függetlenül milyen problémákkal terhes, más elméletek tárgyát kell, hogy képezze. Jensen és Meckling (1976) szerint a tőketulajdonosoktól elkülönülten azért születik meg a vállalat, mert a tulajdonos(ok) a releváns kompetenciák hiányai miatt nem képesek feladatot vállalni az adott jószág előállításában. Másik ok lehet az, hogy alkalmasak lennének, de nem akarnak, bizonyos egyéni preferenciák miatt. Harmadrészt elképzelhető, hogy alkalmasak is lennének, szándékuk is megvan hozzá, de lehetőségük nincs rá. Ez utóbbi ok a nagyobb részvénytársaságoknál jelentkezik viszonylag gyakran, ahol a tulajdonosoknak sokszor meg kell küzdeniük a személyes részvétel lehetőségéért, az igazgatótanácsi, felügyelőbizottsági helyekért. Összefoglalva tehát a tulajdonosoktól elkülönült menedzsment a vállalatok létét, határait úgy magyarázza, hogy a jószág-előállítás, különösképpen annak irányítása többlet-kompetenciát, kompetenciák kritikus tömegét igényli, amely gyakran meghaladja a tulajdonosokét. Ezt a logikai vonalat ugyanakkor - mint azt majd később láthatjuk - már a kompetenciaelmélet dolgozza ki jobban. A megbízó-ügynök vállalatelmélet szerint a vállalat méretének az szab határt, hogy a megbízó mekkora költségáldozattal képes olyan szinten uralni az ügynök menedzsmentet, hogy céljai eredményesen megvalósuljanak. Amennyiben a várható hasznot meghaladja ez az ellenőrzési, uralási költség, az azt jelenti, a vállalat relatíve már túlságosan nagyméretü. Azzal, hogy a megbízóügynök elmélet kiterjeszthető a menedzsment és a munkavállalók viszonyrendszerére is, az elmélet kiemelt figyelmet tud szentelni valamennyi csoporttag érdekének, motivációinak, jutóinak. A csoporttagok tevékenységével egymásnak okozott kockázattal, illetve bizonytalansággal, az ezek minimalizálását szolgáló szervezeti válaszokkal is magas szinten foglalkozik ez az elmélet. Annak ellenére, hogy az információs aszimmetriára kiemelt figyelem irányul, a termeléshez szükséges „mérnöki” és dolgozói szaktudás kérdése, illetve menedzselése a háttérben marad csakúgy, mint a pénztőkén kívüli anyagi erőforrások, technológiák kezelése.

Coase (1937) lefektette az alapelveit annak, hogy a tranzakciós költségekkel miként magyarázható a vállalatok vagy más szervezetek - léte. A tranzakciós költségek az adott jószág vételárán túli terhek, melyeket az adott vásárlási döntés - ami lehet nemleges is - vonatkozásában a vevő vállalni kényszerül, vagy racionális szereplőként érdemes vállalnia.

A tranzakciós költségeket azért fizeti meg a szereplö, hogy a releváns bizonytalanság mértékét, más szereplők tevékenységéből fakadó kockázati kitettségét csökkentse (Foss, 
1997). Ebből adódóan minél nagyobb egy piacon a bizonytalanság s a kockázat, valószínűleg annál nagyobb tranzakciós költséget igényel csökkentésük, így annál hatékonyabb megoldást eredményezhet egyes szereplők számára a vállalat határainak kitolása, egyes tevékenységek, erőforrások integrálása. Williamson (1985) még hangsúlyosabbá tette azt, hogy a tranzakciós költségeket a piaci résztvevők lényegében egymásnak okozzák. Részben azért, mert nem biztosítanak megfelelő információkat egymásnak, másrészt igyekeznek önmaguknak kedvezőbb feltételeket kiharcolni a szerződéskötésnél, illetve utóbb visszaélnek a szerződés hiányosságaival. A legtöbb költséget ilyen szempontból azok a partnerek okozhatják, akik egyedi jószágára a szereplő nagy gyakorisággal rászorul. Ha e rászorultság még a másik fél információs fölényével is párosul, akkor az ő függetlensége olyan mértékü bizonytalanságot és kockázatot eredményez, amely csak jelentős tranzakciós költségek mellett csökkenthető egy kívánatos szint alá. A tranzakciós költség vállalatelmélet igyekszik - a neoklasszikus vállalatelmélethez hasonlóan számszerűsíthetővé, matematikailag modellezhetővé tenni a vállalati méret változásait a vállalat létrejöttétől kezdve annak megszünéséig. Végső soron ez az elmélet a partnerkockázatról, a tényleges és potenciális vállalati üzletfelek által okozott kockázatok és bizonytalanság kezeléséről szól. Ezekre a kockázatokra, illetve bizonytalanságra ad valamilyen szervezeti választ az elmélet által vizsgált vállalat. Kiemelt szerep jut az elméletben a partnerek által birtokolt erőforrásoknak is, és nem csak az anyagiaknak. Az érintett tulajdonosokon túl azonban lényegében nem fordít figyelmet a többi csoporttag szempontjaira, jellemzőire, mint ahogy a szellemi jellegü erőforrások hozzáférhetőségének kérdéskörére sem.

A tranzakciós költségeket másféleképpen is csökkenteni lehet, mint amit a tranzakciós költségek vállalatelmélete erre vonatkozóan ajánl. Ott a két fó alternatíva a beolvasztás, illetve a kiszervezés voltak. Langlois (1992) ugyanakkor ezzel összefüggésben rámutatott arra, hogy a vállalatok tudása, az ebből fakadó információs igénye, a tanulási, tanítási, döntéshozatali, illetve együttmüködési és kikényszerítési képességei az idővel változnak, ami más, árnyaltabb, összetettebb technikákat is megkíván a tranzakciós költségek csökkentése érdekében. A vállalatok részéről az ún. dinamikus tranzakciós költségek akkor merülnek fel, amikor igyekeznek egymással összehangolni azt a tudásukat, és azokat a képességeiket, amelyek a folyamatosan változó müködési környezethez való alkalmazkodáshoz szükségesek. Ebben az esetben tehát nem a beolvasztás, illetve a kiszervezés az alternatívák, hanem a tanulás és tanítás. Ez a gyakorlatban például licenc értékesítését vagy vásárlását jelenti, vagy sorozatos interakciókkal egymás csiszolgatását, kiismerését. A dinamikus tranzakciós költségek elméletét Kapás (2000) sok szempontból a legígéretesebb új vállalatelméleti irányzatnak tartotta. Nem véletlenül. A tranzakciós költségek elméletéhez képest sokkal nagyobb hangsúly került a humán erőforrásra, a tudásra, a vállalati képességekre, illetve ezeknek az alkalmazkodás érdekében történő folyamatos fejlesztésére. Ezzel közel került ez az elmélet a kompetencia-, illetve képességalapú elméletekhez is. A kockázatokra és a bizonytalanságra, illetve az azokra adandó szervezeti válaszokra hasonlóan nagy figyelem irányul, mint a tranzakciós költségek elmélete esetében, ugyanakkor a csoporttagok érdekei, az ő „,jutóik” - melyek a dinamikus tranzakciós költségek megfelelő hasznosulása szempontjából meghatározóak - ennek a vállalatelméletnek is alig képezik részét.

Geraghty (2007) az angol ipari forradalmat tanulmányozva kimutatja, hogy a komplementaritás milyen lényegi szerepet töltött be a gyáripar kialakulásában. A drága, egymásra épülö technológiák egy helyen való integrálása révén lehetett csak megfelelő minőséget elérni, megfelelö ösztönzőket kialakítani, s megfelelő megtérülést elérni. Mindebben meghatározó szerepe volt a vállalaton belüli mérés nagyobb hatékonyságának, megbízhatóságának, a döntéshozatal felgyorsulásának, a saját alkalmazottak könnyebb irányításának, befolyásolásának. Geraghty (2007) szerint a komplementaritásban lényegében az egymás termelési hatékonyságától való függés fejeződik ki, s a kellő összhang elérésében - azaz a tranzakciós költségek csökkentésében - nagy szerephez juthat az egymással komplementer viszonyban álló tevékenységek egy vállalatba való szervezése. Ilyen módon ezek a vállalatok, bár egymástól függnek jószágaik közös fogyasztása miatt, közvetlenül nem okozhatnak egymásnak tranzakciós költséget. Ugyanakkor - például a sí-iparban mégis célszerü tevékenységük bizonyos mértékü összehangolása. Együttmüködésük lehet laza, de szoros szövetség is, vagy akár egyesülés, egymásba olvadás is. Amennyiben az ellátási lánc egyes elemei, vagy akár az összes is egy vállalaton belülre kerülnek, akkor az értéklánc részeit képezve egymást, s kiváltképp a „fötevékenységet” támogatják (Chikán, 1997). A komplementaritás vállalatelméletében az egyesülés vagy a beolvasztás, illetve a kiszervezés nem a korábban a tranzakciós költségek elméleténél említett ún. partnerkockázatok függvénye. Esetünkben tisztán technológiai, illetve általában véve erőforrás-hatékonyságról, annak növeléséről van szó. A termelési, a „mérnöki” oldalról jelentkező kockázatokkal és bizonytalansággal összefüggésben adott szervezeti válaszok, az anyagi és szellemi erőforrások tekintetében jól kidolgozott ez a vállalatelmélet. Sajátos módon azonban a csoporttagok komplementaritásával, összehangolásukkal, érdekeltté tételével nem foglalkozik érdemben.

A kompetencia (competence) alapú vállalatelméletek a vállalat létének és túlélésének alapját abban látják, hogy milyen (szak)tudásszeletkéket, azaz kompetenciákat, azok milyen kombinációját képes összegyüjteni, birtokolni. A kompetenciák ugyanis nem egyformán oszlanak meg a piaci szereplők között, ezáltal tevékenységük, müködésük sem lehet egyformán eredményes. A különböző szintű eredményesség különböző színvonalú és valószínüségű túlélést tesz lehetővé. Henderson és Cockburn (1994) szerint a kompetencia hozzáértést jelent, az adott tevékenység, jószág-elöállítás folytatásához szükséges tudásrészt. E tudásrészbe beleértik a gyakorlat során szerzett jártasságot, ügyességet, összecsiszolódást, az úgynevezett tacit tudást is, amely meghatározott anyagi erőforráshoz, technológiához való hozzáférést feltételez. Ugyanakkor egyes kompetenciák valójában használhatatlanok, sőt egyenesen negatív értéküek is lehetnek. Ebböl adódóan a kompetenciák leltárára épített elmélet magyarázó erejét Kogut és Zander (1992) nem tartják megfelelően erősnek, csak a jelenre, illetve a jelent tartalmazó rövid időperiódusra, ciklusra vonatkozóan. Valóban, a kompetenciaelmélet 
olyan tudáselemeket is leltárba venne, melyek sem a jelenben, sem valószínüleg a jövőben nem hasznosulnak, semmilyen módon nem szolgálják a vállalat érdekeit. Az ilyen értelemben vett passzív tudásról vagy nincsenek információi a döntéshozóknak, vagy nem tartanak rá igényt, feleslegesnek itélik. Így a kompetencialeltár nem a vállalat valódi erejét, nem a valós „egyéniségét” mutatja. A csoporttagok csoport szolgálatába állítható tudásának hiányos számbavétele, a tudás felhasználásának, kiaknázásának alacsony mértéke és színvonala a tudás értékelésének torzulásaihoz vezethet. Ez is mutatja, hogy ez az elmélet nem kellően kiforrott a csoporttagok célmegvalósításának figyelembevételében, kezelésében. A tudásszint ugyanakkor nagyon szoros összefüggésben áll azzal a kockázati és bizonytalansági mértékkel, melyek mellett a csoport a tevékenységet folytatja. Ezzel a szervezeti megoldások és a megszerzett tudás szintén közvetlen összefüggésben állnak, az elmélet még sem fektet kellő hangsúlyt erre a területre sem. A vállalat által birtokolt tudás másik kapcsolódó területe - a kézenfekvő humán erőforráson túl - az anyagi erőforrások, illetve egyéb szellemi javak. Ezt a kapcsolatrendszert az elmélet - ha közvetetten is -, de érdemben kezeli.

Prahalad és Hamel (1990) kísérletet tettek arra, hogy kiküszöböljék a kompetenciaelmélet általuk vélt hiányosságait akkor, amikor bevezették a magkompetencia elméletét. Szerintük a kompetenciák számbavételének eleve csak olyan vállalatnál van jelentősége, mely többféle jószág-elóállitó tevékenységet folytat. A diverzifikált vállalat olyan, mint egy fa, ahol az egyes termékek a gyümölcsök, de a lényeg a gyökérszinten rejlik. Ez adja a stabilitást, veszi fel a tápanyagot, irányítja az anyagcserét, gyakorlatilag itt dől el a versenyképesség kérdése. E szintet a magkompetenciákkal jellemezhetjük (Prahalad \& Hamel, 1990). Nyilvánvaló, hogy a magkompetenciák sem maradhatnak változatlanok, ezeket is fejleszteni, bővíteni kell. A magkompetencia-modell egy dinamikus modell, szüntelen építkezést jelent, de ebben a magkompetenciák kell, hogy elsőbbséget élvezzenek, hiszen a többi kompetencia általuk újulhat meg, épülhet be a vállalat müködésébe. Magkompetenciát viszonylag időigényes kiépíteni, teljesen egyedi, ezért azt más szereplő nehezen képes másolni. A magkompetenciák kialakításában elsődleges a felső vezetés szerepe és felelőssége. Számbavétele talán annyiban lehetne könnyebb, hogy kevésbé egyénspecifikus, ilyen módon kevesebb a rejtőzködő magkompetencia egy vállalatnál, mint a többi, ezekre egyedileg épülő kompetencia. Mivel azonban a magkompetencia általánosabb szaktudást jelent, így annak anyagi és egyéb szellemi erőforrásokhoz, konkrét technológiákhoz való kapcsolódási pontjai is kisebb számban jöhetnek létre. A magkompetencia-elmélet magyarázó ereje tehát e tekintetben kisebb, mint a kompetenciaelméleté. Ugyanígy a kevesebb kapcsolódási pont a csoporttagok célmegvalósítási eredményessége vonatkozásában is mérsékli az elmélet erejét. A szervezeti megoldásokkal mérsékelhető kockázatok és bizonytalanság tekintetében viszont előbbre lépett ez az elmélet a kompetenciaelmélethez képest, hiszen erőteljesebben megjelenik az alkalmazkodási igény, $\mathrm{s}$ az abban bizonyos tudáselemek által betöltött szerep.

Trigeorgis (1996) szándéka szerint megmaradva az erőforrás-elméleten belül, elsődlegesen a képességek (capability) meghatározó voltát hangsúlyozta. Hogy milyen kondí- ciót, erőforrás-kollekciót lesz képes elérni, összegyüjteni a vállalat, az a benne rejlő képességeken is múlik. Képességek kellenek a szükséges források bevonásához, akár tulajdonostársak, akár hitelezők révén. A döntéshozatali képességek is nagyon lényegesek, $\mathrm{s}$ általában a humán erőforrás képességeinek további építésére vonatkozó adottságok is szükségesek. A változó környezet miatt a szinten tartáshoz, de a fejlődéshez-növekedéshez még inkább meghatározó a tanulásra, illetve innovációk létrehozására való képesség. Sveiby (2001) rámutatott, hogy a kompetenciák a szervezeti tagokhoz kapcsolódnak, ugyanakkor az, hogy ezek ténylegesen milyen szerepet játszanak a vállalat értékének meghatározódásában, attól függ, hogy a külső és belső szervezeti struktúrával kapcsolódva milyen mértékben képesek részt venni a tudás szállításában és átalakításában. A szervezeti felépítés a személyes kompetenciákhoz hasonló jelentőségü abban, hogy végül is milyen képességeket, és általuk lehetőségeket birtokol egy vállalat (Kang, Rhee \& Kang, 2010). A képességek termelik, termelhetik ki folyamatosan a mindenkori kompetenciákat, a hozzáértés aktuális területeit. A képesség-vállalatelmélet már az alkalmazkodás, a fejlődés igényének rendelte alá a vállalat által birtokolt speciális szellemi jószágot, a képességeket, melyet a speciális szaktudástól könnyebben, általában a tudástól nehezebben lehet elhatárolni. Mivel ez az elmélet sokkal általánosabban állítja a középpontba a szelekciós követelményeknek való meg nem felelés problematikáját, így magyarázó ereje is sokkal nagyobb a kockázatok és bizonytalanságok szervezeti megoldások révén való kezelésében, mint a két kompetenciaelméleté. A képességek viszont, ha lehet, még általánosabb, még kevésbé specifikus szellemi javak, mint a magkompetenciák. Így az elmélet a csoporttagok célmegvalósításához, illetve az anyagi erőforrásokhoz, technológiákhoz még kevesebb kapcsolódási pontot tudott kialakítani. Ugyanakkor a szükséges kompetenciákhoz való tényleges - képességek által megalapozott - hozzáférésének kérdése ebben az elméletben sokkal kimunkáltabb, mint az a két kompetenciaelmélet esetében történt.

Teece (2017a) már megkülönbözteti egymástól az úgynevezett szokásos képességeket, illetve a dinamikus képességeket. A szokásos képességek rendszeresen ismétlődő, azonos célzatú, állandó követelményrendszerrel bíró, azonos eredménnyel záródó tevékenységek elvégzéséhez kapcsolódnak. „Csináljuk a dolgokat jól!” (Teece, 2017b, p. 696). E tevékenységeknek a kiegyensúlyozott és magas színvonalú eredményessége, technológiai hatékonysága azt bizonyítja, hogy a vállalat megfelelő mértékben rendelkezik a szokásos képességekkel. Ilyen képességek szükségesek a termelés megszokott tevékenységeinek végrehajtásához, vagy a mindennapi adminisztratív feladatok ellátásához, de a rutinszerü tanuláshoz is. A szokásos vállalati képességek Teece (2017a) szerint - a klasszikus csoportmunka kivételével - lényegében az egyéni képességekből összegződnek, természetesen figyelembe véve a vállalat eszközellátottságát is. A dinamikus képességek alkalmazásával a vállalat célja Teece $(2017 \mathrm{~b}, \mathrm{p}$. 698) az, hogy „Jó dolgokat csináljunk”. Itt már nem az alaptevékenységek szüntelen tökéletesítéséröl, hanem arról van szó, hogy a profitabilitás növelése érdekében a vállalatnak időnként - a kellö időben - meg kell újulnia. Meg kell újítania az erőforrásait - kiváltképp az emberi erőforrásokat -, azokból 
új konfigurációkat kell létrehoznia válaszul a változásokra, illetve változásokat is generálva. A dinamikus képességek révén kell a vállalatnak érzékelnie (sensing) a kihívásokat, elsősorban a vevői követelmények terén. Másrészt a számos szigorodó követelménynek való növekvő megfelelés, azaz az értékteremtés érdekében meg kell tudnia ragadni a kínálkozó lehetőségeit (seizing), vagy meg kell ezeket teremtenie. Végül, folyamatosan - azaz megfelelő sürüséggel - meg is kell újulnia (transforming). A dinamikus képességek e három alapterületét a vállalatnak képesnek kell lennie össze is kapcsolni (Teece, 2017b). Ez a vállalatelmélet rendelkezik az egyik legnagyobb magyarázó erővel a kockázatok, a bizonytalanság, illetve az erőforrások, technológiák hozzáférhetőségében. Azonban a csoporttagok közül lényegében csak a felső menedzsment célmegvalósítása, érdekeltté tétele kap kellő figyelmet. A többi csoporttag célmegvalósítási eredményessége a sikeres felsőmenedzsmenti tevékenység függvénye. Ez kérdésessé teszi, hogy miként is tehet szert a vállalat valódi, a gyakorlatban is müködőképes dinamikus képességekre, majd azok által további képességekre, illetve kompetenciákra.

Az ún. stakeholder-elmélet elsősorban Edward Freeman (1984), a stratégiai menedzsment elméletének képviselője nevéhez köthetö, és azt kívánja megjeleníteni, hogy nemcsak a tulajdonosok és munkavállalók közös akarata szerint épül fel egy vállalat, hanem arra lényegi hatást gyakorolhatnak más érdekeltek is. A vállalatelmélet „stakeholder” irányzata sajátos módon elegyíti, de gazdagítja is a tranzakciós költség és a magatartási elméleteket, mint arra Freeman és Evan (1990) rámutattak. Clarkson (1995) a stakeholdereken belül megkülönbözteti az elsődleges és a másodlagos érintetteket. Az elsődleges stakeholderek közé azok tartoznak, akik támogató együttműködése, azaz a vállalati döntéshozatalok során ehhez szükséges megfelelő érdekelismerése nélkül a vállalat léte, túlélése egyáltalán nem biztosítható. Ide tartoznak általában véve a dolgozók, menedzsment, tulajdonosok, de ezen túl, akár egy müködési engedélyt kiadó hatóság is elsődleges stakeholder lehet - a szükséges ideig. A másodlagos csoport tagjai szintén fontosak, de az ő támogatásuk „csupán” a vállalat hatékonyságát növeli, a valószínű túlélés állapoti jellemzöire hat pozitívan. Mitchell, Agle és Wood (1997) szerint ahhoz, hogy valaki stakeholder legyen, három feltételnek kell együttesen megfelelnie. Legyen a vállalat müködése által érintett, ez az érintettség legyen valamilyen szempontból fontos számára, és legyen valamilyen hatalma a vállalat müködésére hatást gyakorolni. „A stakeholder-elmélet korrekt módszert ad nekünk a vállalkozói kockázatról való gondolkodásra" (Freeman, Wicks \& Parmar, 2004, p. 366). Valóban, ez a vállalatelmélet azzal, hogy a vállalat létrejöttét, változásait az érintettekre alapozta, a nem emberi eredetü környezeti okok kivételével szinte valamennyi kockázati és bizonytalansági problémát eredményező okot becsatornázta az elemzés keretei közé. Az érintettek köre még bővebb is, mint a csoporttagoké. Ugyanakkor minden olyan érintett, aki pillanatnyilag nem csoporttag, a jövőben még azzá válhat, tehát potenciális csoporttagként kezelhető. A vállalatelmélet tehát a tényleges és potenciális csoporttagok teljes körét vizsgálat alá vonja, s nemcsak az érintettség, hanem az egyéni célkitűzések, illetve azok eredményes megvalósítása kérdé- sében is. Az érintettek érdekeire alapozva, de a végső soron mögöttük meghúzódó egyénekből kell a vállalat szervezetét létrehozni. Úgy, hogy eközben folyamatosan szem előtt kell tartani a csoporttagok által hozzáférhetővé tett erőforrásokat, technológiákat, képességeket és kompetenciákat, továbbá a tagok egy szervezetbe való integrálása révén csökkenthető kockázatokat és bizonytalanságot is. Ez az elmélet is dinamikus, hiszen a folyamatos változások miatt folyamatosan átalakul a külső és belső érintettek köre, illetve az egyes érintettekhez „kapcsolódó” erőforrások, kockázatok, illetve bizonytalanság is.

Nelson és Winter (1982) immár kifejezetten a biológiai evolúció alaplogikáit felhasználva próbáltak magyarázatot adni a gazdasági növekedésre, fejlődésre, egyensúlyra, illetve az innovációra, de általában a vállalat létezésére, fennmaradására is. Az ún. evolúciós vállalatelméletben Nelson és Winter (1982) számára egyértelmü, hogy a vállalat több annál, mintsem hogy az anyagi és nem anyagi jellegü javak kombinációival egyértelműen leírható lenne. A gazdasági evolúció elméletében tehát a géneket nem tőkével, munkaerővel, forgóeszközökkel és egyéb fizikai tényezőkkel helyettesítette, hanem úgynevezett vállalati rutinokkal (u.o.1982, p. 14). A rutinok felölelik a vállalat összes, többé-kevésbé rögzült szokását akár a termelés vonatkozásában - ezek a technológiai tevékenységek vállalatra jellemző szakmai protokollját jelentik -, akár a döntéshozatal, vagy általában a vállalati kultúrával összefüggésben. Nelson és Winter (1982) szerint a rutinok mintázata azért jellemzi még egyértelmübben a vállalatot, mert a rutinokban „megtestesül” a vállalat rendelkezésére álló mindenkori tudás, annak fejlődési lehetőségei, de a fizikai erőforrások is. A rutinok a vállalat felhasznált kompetenciái által határozódnak meg. A rutinok egymással komplex módon kapcsolódnak össze, létrehozva a vállalat képességeit. E rutinokból álló rendszer azonban folyamatos - hatékonyságnövelő célú - átalakulásban van, s az átalakulás iránya a korábbi rendszer által lényegileg meghatározott. Ez a vállalatelmélet a „tettek beszélnek” elvére épül. A rutinokban testesül meg elvileg valamennyi, a vállalat müködéséhez szükséges, aktuálisan hozzáférhető erőforrás, technológia, képesség és kompetencia. Ugyanakkor ez a hozzárendelődés nem kölcsönösen egyértelmű. Azonos vállalati rutinok mögött is meghúzódhatnak eltérő anyagi és szellemi erőforrások, technológiák, eltérő képességek és kompetenciák. Ugyanakkor ugyanolyan háttér is eredményezhet eltérő rutinokat, elég, ha csak a szerencse, balszerencse szerepére utalunk például az innovációkban. Ilyen értelemben tehát ez a vállalatelmélet a felszínt mutatja, érdemben nincs szerepe sem a tartalékoknak, illetve - az elmélet gyökereihez képest furcsa módon - a csoporttagok jutójának, az ö érdekeiknek. Mivel ez egy dinamikus vállalatelmélet, így a kockázatokat és a bizonytalanságot a szervezeti innovációk homlokterében tartja, hiszen az fontos szerepet tölt be a gazdasági evolúcióban. Minél jobban tágítjuk az elemzési időhorizontot, annál inkább. Ugyanakkor a kockázatok és a bizonytalanság szervezeti megoldásokkal való kezelése ebben az elméletben nincs olyan közvetlenül összekapcsolva a hozzáférhető erőforrásokkal, illetve a csoporttagok összetételével, mint a stakeholder elméletben. 


\section{Konklúzió}

Inglehart (2018) találóan mutatott rá, hogy minden időszakban az a társadalmi érték válik elsődleges fontosságúvá, amelyik tekintetében relatíve szükösre fordultak a viszonyok. E viszonyokat érzékelve, elemezve a szakértők hajlamossá válnak minden probléma legjelentősebb okaként ennek az értéknek a deficitjét feltüntetni. Eközben természetesen a sikeres gyakorlat - az adott elmélet alapján - leginkább a szóban forgó társadalmi értéken alapulhat. A röviden áttekintett vállalatelméletek esetén is helytálló lehet ennek a hipotézisnek az alaplogikája. Jellemző a vállalatelméletekre, hogy azon ok-okozati viszonyokra fókuszálnak, melyek elsődlegesen tüntek, tủnnek fontosnak a vállalat létrejöttekor, illetve életciklusában. Abban az időszakban, amikor a jól képzett, elkötelezett munkaerő bőven rendelkezésre állt, $\mathrm{s}$ az anyagi erőforrások képezték a termelés szük keresztmetszetét, természetes, hogy a vállalatelmélet az anyagi erőforrások meglétére, összetételére koncentrált. Amikor a szaktudáshoz való hozzáférésben alakultak ki nagy különbségek, a vállalatelméletekben a hangsúly is áttevődött a kompetenciákra. Amikor a humán erőforrás homogenitása jelentősen csökkent, akkor a csapatépítés kérdése vált jelentőssé. Mikor alapvető alkalmazkodási képességek terén mutatkoznak alapvető problémák, a vállalatelméletek ezekre vezetik vissza a vállalati sikerességet. Kapás (1999b) kívánatosnak tartotta volna egy olyan „többdimenziós” vállalatelmélet létrehozását, amely egyszerre több, a vállalat létrehozása és müködése során meghatározó tényezőt vesz figyelembe, s képes ezek hatásait öszszekombinálni. Jelen tanulmány természetesen nem vállalkozhatott ennek az óriási feladatnak az elvégzésére. Ugyanakkor e vonatkozásban láttatni kívánta a vállalatelméletek sokszínűségét, illetve azt, hogy bizonyos időszakban, bizonyos feltételek között mindegyik megfelelő magyarázó erővel rendelkezik.

$\mathrm{Az}$ ismertetett vállalatelméletek majd mindegyikének - el nem ítélhető módon - közös jellemzője az, hogy a vállalat mint rendszer, annak önálló léte szempontjából vizsgálódnak. Miközben a vállalat nem öncélúan jön létre, $\mathrm{s}$ müködik hosszabb-rövidebb ideig. Ez akkor is nyilvánvalóvá válhat, amikor a vállalat megszünik. Ekkor ugyanis már teljesen megalapozottan kijelenthetjük azt, hogy a vállalat által fennállása alatt létrehozott összes érték - legyen az pénz formájában megjelenő vagy kifejezhetö, vagy sem, a pozitív externáliák kivételével - a vállalat mint csoport tagjait gazdagította, gyarapította. A vállalati lét által teremtett többletérték szét- és visszasugárzódik a csoporttagokra Ez a megszerzett érték csoporttagok számára egyfajta szelekciós elönyt biztosíthatott, pontosan ez volt, ez lehetett az ok, amiért csoporttagokká váltak. Érdemes tehát a vállalatelméleteknek erre a területre, a csoporttagok célmegvalósítási eredményességi szempontjaira is kellő figyelmet forditaniuk. Mint láthattuk, a csoportszelekció logikája az evolúciós közgazdaságtan egyik meghatározó eleme. Ebből adódóan talán mindenki joggal várhatta el azt, hogy az evolúciós vállalatelmélet végre kellő hangsúlyt helyez a csoporttagok érdekeire, a vállalat általi célmegvalósitásukra. Ahogyan erre Kapás (1999b) is rámutatott, az evolúciós vállalatelmélet ezzel adós maradt. Az evolúciós vállalatelmélethez képest jelen tanulmány azonban a csoporttagok nézőpontjára kiemelt hangsúlyt helyezett. Ilyen módon - az erőforrásokhoz, technológiákhoz való hozzáférés, illetve a kockázat és bizonytalanság szervezeti kezelése mellett
- ez vált a harmadik, $\mathrm{s}$ egyben legfontosabb tényezővé, amely szerint áttekintésre kerültek a különböző vállalatelméletek. Az áttekintés eredményeit a 2. ábra kívánja szemléltetni.

\section{2. ábra Vállalatelméletek a három dimenziós térben}

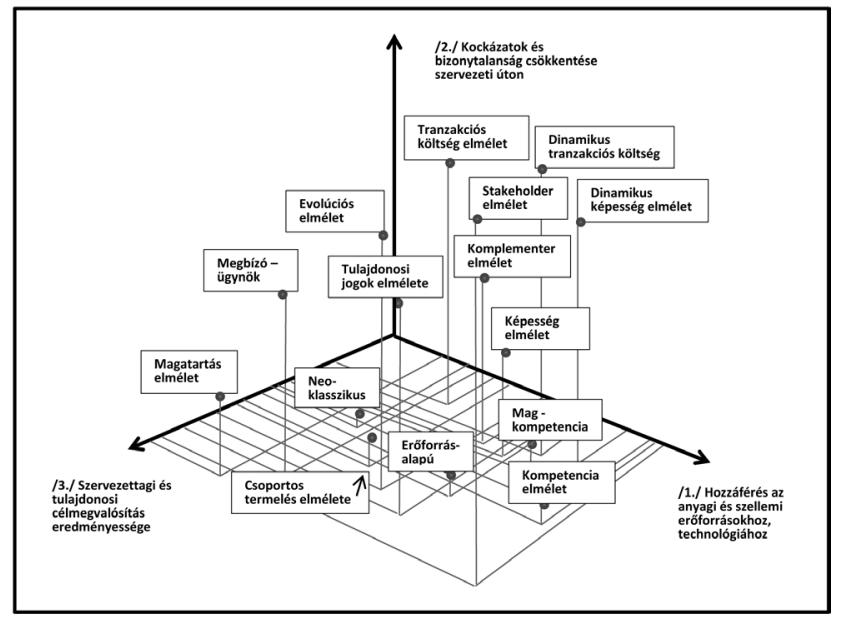

Forrás: saját szerkesztés

Az áttekintő elemzés eredményeképpen megállapíthatjuk, hogy az ún. stakeholder vállalatelmélet az, amely úgy fordít kellő figyelmet a csoporttagok célmegvalósítási eredményességére, azaz az általuk a vállalat müködése révén elérni kívánt szelekciós előnyökre, hogy eközben a másik két vizsgált tényező is ehhez hasonló hangsúlyos szerephez juthat. Természetesen az lenne a legkívánatosabb állapot, ha egy vállalat müködése minden érintettre pozitív hatást gyakorolhatna. A már eleve, vagy várhatóan, tervezetten pozitív módon érintettek kölcsönösen kedvezö ajánlat esetén a vállalati szervezetbe, vagy a tulajdonosi körbe integrálhatók. Az így létrejövő csoport tagjai bizonyos erőforrásokat, technológiákat, de képességeket, kompetenciákat is hozzáférhetövé tesznek a csoport számára. A kölcsönösen elönyös ajánlat mibenléte üzleti kalkulációk révén határozódik meg, többek között a tranzakciós költségek figyelembevételével. A leendö csoporttag részére felkínálható előny vagy érték nem feltétlenül kell, hogy pénzbeli vagy pénzben kifejezhető legyen. Hámori és Kapás (2002) megalapozottan javasolták azt, hogy az érzelmek is kerüljenek figyelembevételre a vállalatelméletekben. Különösen érdekes azonban a negatív módon érintettek csoportba való bevonásának kérdésköre. Egyrészt a hozzáférhető erőforrások, technológiák, másrészt a kockázatok, illetve a bizonytalanság szempontjából. Az ő megnyerésük révén tehát akár drasztikusan is csökkenhetnek a kockázatok, illetve a bizonytalanság. Ehhez azonban a vállalatnak olyan módosításokat kell végrehajtania müködésében, vagy a lehetséges ,jutó” tekintetében - amelyek révén a kezdetben még negatívan érintettekből később pozitívan érintettek válhatnak. Ilyen módon talán a mindenkori vállalati müködést, illetve aktuális jövőbeni terveket támogató stakeholder bázis nagysága, összetétele lehet a vállalat génkészlete, nem pedig az evolúciós vállalatelmélet által javasolt rutinok. A stakeholder bázis alapján határozódik meg ugyanis a vállalatáltal hozzáférhetö erőforrások, technológiák, képességek, kompetenciák köre, az ezekből, illetve a szervezeti megoldásokból adódóan vállalni kényszerült kockázat és bizonytalanság döntő része, továbbá végső soron a csoporttagok ,jutója”, célmegvalósítási eredményessége. 
2. táblázat Vállalatelméletek rangsora az egyes problémacsoportokra vonatkozó magyarázóerejük szerint

\begin{tabular}{|l|l|l|l|}
\hline Helyezés & $\begin{array}{l}\text { Hozzáférés az anyagi és szellemi } \\
\text { eröforrásokhoz, technológiához }\end{array}$ & $\begin{array}{l}\text { Kockázatok és bizonytalanság } \\
\text { csökkentése szervezeti úton }\end{array}$ & $\begin{array}{l}\text { Szervezettagi és tulajdonosi cél- } \\
\text { megvalósítás eredményessége }\end{array}$ \\
\hline 1. & Stakeholder elmélet & Stakeholder elmélet & Magatartáselmélet \\
\hline 2. & Kompetenciaelmélet & Din. tranzakciós költség e. & Stakeholder elmélet \\
\hline 3. & Dinamikus képességek e. & Tranzakciós költségek e. & Megbízó-ügynök elmélet \\
\hline 4. & Magkompetencia-elmélet & Dinamikus képességek e. & Tulajdonosi jogok elmélete \\
\hline 5. & Din. tranzakciós költség e. & Evolúciós vállalatelmélet & Evolúciós vállalatelmélet \\
\hline 6. & Erőforrás-alapú elmélet & Tulajdonosi jogok elmélete & Csoportos termelés e. \\
\hline 7. & Komplementer termelés e. & Megbízó-ügynök elmélet & Eröforrás-alapú elmélet \\
\hline 8. & Képességelmélet & Komplementer termelés e. & Komplementer termelés e. \\
\hline 9. & Tulajdonosi jogok elmélete & Képességelmélet & Neoklasszikus vállalati e. \\
\hline 10. & Evolúciós vállalatelmélet & Magatartáselmélet & Magkompetencia-elmélet \\
\hline 11. & Csoportos termelés e. & Magkompetencia-elmélet & Dinamikus képességek e. \\
\hline 12. & Tranzakciós költségek e. & Csoportos termelés e. & Képességelmélet \\
\hline 13. & Megbízó-ügynök elmélet & Eröforrás-alapú elmélet & Komplementer termelés e. \\
\hline 14. & Neoklasszikus vállalati e. & Kompetenciaelmélet & Din. tranzakciós költség e. \\
\hline 15. & Magatartáselmélet & Neoklasszikus vállalati e. & Tranzakciós költségek e. \\
\hline
\end{tabular}

Forrás: saját szerkesztés

Úgy tűnik tehát, hogy a csoporttagok szelekciós előnyeinek nézőpontjából többé-kevésbé valamennyi tárgyalt vállalatelmélet képes valamit mondani (2. táblázat). De magát a nézőpontot csak egyedül a stakeholder elmélet helyezte érdeklődésének homlokterébe. Nem véletlen, hogy a tárgyalt vállalatelméletek közül csak ennek a gyakorlati alkalmazása nyert általánosan teret az üzleti életben. Nemcsak a projektmenedzsmentben - a stakeholder bázis létrehozása során -, hanem a vállalat általános müködtetése során is. Ugyanakkor látni kell, hogy az egyes elméleteket - a közgazdasági hasznosság kategóriához hasonlóan - nem lehet egy-egy mérőszámmal ellátni annak érdekében, hogy értékelni tudjuk azt, hogy bizonyos szempontok tekintetében milyen mértékü magyarázó erővel rendelkezik. Amit viszont kellő tudományos megalapozottsággal megtehetünk az az, hogy - hasonlóan a fogyasztó preferenciarendszeréhez - egymáshoz viszonyítjuk az egyes elméleteket. Nincs, és nem is lehet itt szó győztes vagy vesztes hirdetéséröl, de a viszonylag sok vállalatelmélet között nem hátrány, ha rendelkezésre áll egy kis segítség, útmutatás a jobb tájékozódás érdekében. Erre tett kísérletet ez a tanulmány.

\section{Felhasznált irodalom}

Alchian, A. A., \& Demsetz, H. (1972). Production, information cost, and economic organization. American Economic Review, 62., 777-795. https://www.jstor.org/stable/1815199

Basu, S., Pascali, L., Schiantarelli, F., \& Servén, L. (2009). Productivity, welfare, and reallocation: Theory and firm-level evidence. Working paper series no. 09-19. Boston, MA: Federal Reserve Bank. DOI: 10.3386/w15579

Baumers, M. et al. (2016). The cost of additive manufacturing: machine productivity, economies of scale and technology-push. Technological Forecasting and Social Change, vol. 102.. 193-201. https://doi.org/10.1016/j. techfore.2015.02.015

Bockman, J. (2011). Markets in the name of socialism: The left-wings origins of neoliberalism. Stanford, CA: Stanford University Press.

Bolton, P., \& Dewatripont, M. (1994). The firm as a communication network. The Quarterly Journal of Economics, 109, 809-839. https://doi.org/10.2307/2118349
Chandler, A. D. (1990). Scale and scope: The dynamics of capitalism. Cambridge, MA: Harvard University Press.

Chikán, A. (1997). Vállalatok és funkciók integrációja "Versenyben a világgal” kutatás. Folyamatjellegű irányítás alprojekt zárótanulmánya. Budapest, Magyarország: Budapesti Közgazdaságtudományi Egyetem, Vállalat-gazdaságtan Tanszék.

Chikán, A. (2005). Vállalatgazdaságtan. Budapest, Magyarország: Aula Kiadó.

Chikán, A. (2014). Hidak a közgazdaságtan és a gazdálkodástan között: a vállalatelméletek. Magyar Tudomány, 175 (8), 914-917.

Clarkson, M. B. E. (1995). A stakeholder framework for analyzing and evaluating corporate social performance. The Academy of Management Review, 20(1), 92-117. https://doi.org/10.5465/amr.1995.9503271994

Coase, R. H. (1937) The nature of the firm. Economica, 4., 386405. https://doi.org/10.1111/j.1468-0335.1937.tb00002.x

Cyert, R. M., \& March, J. G. (1963). A behavioural theory of firm. New Jersey, NJ: Prentice - Hall Inc.

Deming, W. E. (2000). The new economics: For industry, government, education. Cambridge, MA: MIT Press.

Demsetz, H. (1997). The economics of the business firm: Seven critical commentaries. Cambridge, CA: Cambridge University Press.

Douma, S., \& Schreuder, H. (1991). Economic Approaches to Organizations. London, UK: Prentice-Hall.

Foss, N. J. (1997). The classical theory of production and the capabilities view of the firm. Journal of Economic Studies, 24., 307-323. https://doi.org/10.1108/01443589710175825

Freeman, R. E. (1984). Strategic management: A stakeholder approach. London, UK: Pitman Books.

Freeman, R. E., \& Evan, W. M. (1990). Corporate governance: A stakeholder interpretation. The Journal of Behavioral Economics, 19., 337-359. https://doi. org/10.1016/0090-5720(90)90022-Y

Freeman, R. E., Wicks, A. C., \& Parmar, B. (2004). Stakeholder theory and "The Corporate Objective Revisited". Organization Science, 15.(3), 364-369. https://doi. org/10.1287/orsc.1040.0066 
Geraghty, T. M. (2007). The factory system in the British industrial revolution: A complementarity thesis. European Economic Review, 51., 1329-1350. https://doi. $\operatorname{org} / 10.1016 /$ j.euroecorev.2006.10.004

Hámori, B. \& Kapás, J. (2002). Merre tovább a vállalatelméletben? Egy lehetséges fejlödési út. Competitio, 1., 13-26.

Hart, O., \& Moore, J. (1990). Property rights and the nature of the firm. Journal of Political Economy, 98(6), 1119-1158. https://doi.org/10.1086/261729

Henderson, R., \& Cockburn, J. (1994). Measuring competence? Exploring firm effects in pharmaceutical research. Strategic Management Journal, 15. Special Issue: Competitive Organizational Behavior (Winter, 1994), 63-84. https://doi.org/10.1002/smj.4250150906

Hicks, J. R. (1946). Value and capital: An inquiry into some fundamental principles of economy theory. Oxford, UK: Oxford University Press.

Holmström, B. R., \& Tirole, J. (1989). The theory of the firm. In Schamelensee, R., \& Willig, R. (Eds.), Handbook of Organization 1 (pp. 60-133). Amsterdam, Netherlands: North-Holland.

Inglehart, R. F. (2018). Cultural evolution, people's motivations are changing, and reshaping the world. Cambridge, UK: Cambridge University Press.

Jensen, M. C., \& Meckling, W. H. (1976). Theory of the firm: Managerial behavior, agency costs and ownership structure. Journal of Financial Economics, 3., 305-360. https:// doi.org/10.1016/0304-405X(76)90026-X

Kang, J., Rhee, M., \& Kang, K. H. (2010). Revisiting knowledge transfer: Effects of knowledge characteristic on organizational effort for knowledge transfer. $E x$ pert Systems with Application, 37., 8155-8160. https:// doi.org/10.1016/j.eswa.2010.05.072

Kapás, J. (1999a). Egy új vállalatelmélet: erőforrás-alapú megközelítés. Vezetéstudomány, 30(2), 35-43.

Kapás, J. (1999b). Szükséges-e többdimenziós vállalatelmélet? Az evolúciós vállalatelmélet kritikai összefoglalása. Közgazdasági Szemle, 46(9), 323-341.

Kapás, J. (2000). A tranzakciós költségek tana a vállalatelméletben: Összefoglalás, kritika és új megközelítések. Vezetéstudomány, 31(7-8), 10-24.

Kogut, B., \& Zander, U. (1992). Knowledge of the firm, combinative capabilities, and the replication of technology. Organization Science, 3.(3), 383-397. https://doi. org/10.1287/orsc.3.3.383

Kornai, J. (1971). Anti-equilibrium. Budapest, Magyarország: Közgazdasági és Jogi Könyvkiadó.

Kozák A. (2015). A beillesztési program tartalma és szabályozása. Munkaügyi Szemle, (6), 46-52.

Langlois, R. N. (1992). Transaction-cost economics in real time. Industrial and Corporate Change, 1(1), 99-127. https://doi.org/10.1093/icc/1.1.99

Lewis, M. (2004). Moneyball: The art of winning an unfair game. New York: W. W. Nortan and Company.

March, J. G., \& Simon H. (1958). Organizations. New York: Wiley.

Markowitz, H. (1952). Portfolio Selection. The Journal of Finance, 7, 77-91. https://doi.org/10.1111/j.1540-6261.1952.tb01525.x

Mccloskey, D. N. (1976). English open fields as behavior toward risk. Research in Economic History, 27.(1), 124-170.
Mitchell, R. K., Agle, B. R., \& Wood, D. J. (1997). Toward a theory of stakeholder identification and salience: Defining the principle of who and what really counts. The Academy of Management Review, 22., 853-886. https:// doi.org/10.5465/amr.1997.9711022105

Nash, J., \& Mccloskey, D. N. (1984). Corn at interest: The extent and cost of grain storage in medieval England. The American Economic Review, 74, 174-187.

Nelson, R. R., \& Winter, S. G. (1982). An evolutionary theory of economics change. London, UK: The Belknap Press of Harvard University Press.

Penrose, E. (2009). The theory of the growth of the firm (4th edition). Oxford, UK: Oxford University Press.

Prahalad, C. K., \& Hamel, G. (1990). The Core competence of the corporation. Harvard Business Review, 68.(4), 79-93. https://doi.org/10.1007/3-540-30763-X_14

Progoulaki, M., \& Theotokas, J. (2010). Human resource management and competitive advantage: An application of resource-based view in the shipping industry. $M a-$ rine Policy, 34., 575-582. https://doi.org/10.1016/j.marpol.2009.11.004

Simon, H. A. (1947). Administrative behavior: A study of decision-making processes in administrative organization. New York: Macmillan.

Smith, A. (1776). The wealth of nations. Glasgow, UK: Oxford University Press.

Spulber, D. F. (2009). The theory of the firm: Microeconomics with endogenous entrepreneurs, firms, markets, and organizations. Cambridge, UK: Cambridge University Press.

Surendra, N. C., \& Denton, J. W. (2009). Designing IS curricula for practical relevance: Applying baseball's "Moneyball" theory. Journal of Information Systems Education, 20. (1), 77-85.

Sveiby, K. E. (2001). A knowledge-based theory of the firm to guide in strategy formulation. Journal of Intellectual Capital, 2., 344-358. https://doi. org/10.1108/14691930110409651

Teece, D. J. (2017a). A capability theory of the firm: An economics and (Strategic) management perspective. New Zealand Economic Papers, https://doi.org/10.1080/00779954.2017.1371208

Teece, D. J. (2017b). Towards a capability theory of (innovating) firms: implications for management and policy. Cambridge Journal of Economics, 41, 693-720. https:// doi.org/10.1093/cje/bew063

Trigeorgis, L. (1996). Real options: Managerial flexibility and strategy in resource allocation. Cambridge, MA: MIT Press.

van den Bergh, J. C. J. M., \& Stagl, S. (2003). Coevolution of economic behaviour and institutions: Towards a theory of institutional change. Journal of Evolutionary Economics, 13. 289-317. DOI: $10.1007 / \mathrm{s} 00191-003-0158-8$

van den Bergh, J. C. J. M., \& Gowdy, J. M. (2008). A group selection perspective on economic behavior, institutions and organizations. Journal of Economic Behavior and Organization, 72 (1), 1-20. doi:10.1016/j.jebo.2009.04.017

Williamson, O. E. (1985): The Economic Institutions of Capitalism: Firms, Markets, Relational Contracting; New York, The Free Press, 468. p.

Zerwas, D. (2014). Organizational culture and absorptive capacity. Koblenz Landau, Germany: Springer Gabler. 